Arab World English Journal (AWEJ) Volume 12. Number3 September 2021

DOI: https://dx.doi.org/10.24093/awej/vol12no3.35

Pp. 524-535

\title{
Factors Influencing Non-Native EFL Teachers' Identity Construction at a Saudi School in Kuala Lumpur, Malaysia
}

Juliana Othman

Department of Language and Literacy Education, Faculty of Education

University of Malaya

Corresponding Author: juliana@um.edu.my

\author{
Sultan Fahd Aljuhaish \\ Ministry of Education \\ Saudi Arabia
}

Received: 4/3/2021

Accepted: 6/9/2021

Published: 9/29/2021

\begin{abstract}
In recent years, an increasing number of non-native EFL teachers have been recruited to teach English in English dominant settings. Grounded in sociocultural views of identity, the research question of this study focused on how contextual factors influence the professional identity construction of three EFL teachers in a Saudi School in Kuala Lumpur, Malaysia. The study employs a qualitative case study method, where in-depth interviews and classroom observation are utilised. Drawing on Wenger's (1998) communities of practice framework to analyse and interpret the data, the analysis indicates various factors affecting the EFL Saudi teachers' professional identity. Findings reveal that identity formation is a complex and highly contextual process. The participants in this study construct their identities by engaging in their teaching environment, shared practices with their peers, engaged in student-parents relationship and participated in professional development. Through transitioning into the English as a second language (ESL) setting, the EFL teachers have demonstrated how professional identity is a dynamic and socially situated construct. As a result, these teachers' identities may be transformed by the global educational settings in which they work. The findings contribute to our understanding of the importance of a conducive professional environment in supporting teachers to develop their professional identities.

Keywords: EFL teachers, identity construction, professional identity, Saudi schools
\end{abstract}

Cite as: Othman, J. , \& Aljuhaish, S.F. (2021). Factors Influencing Non-Native EFL Teachers' Identity Construction at a Saudi School in Kuala Lumpur, Malaysia. Arab World English Journal, 12 (3) 524-535. DOI: https://dx.doi.org/10.24093/awej/vol12no3.35 


\section{Introduction}

Globalization and the global dissemination of English have resulted in a massive demand for English mastery all over the world. English language teachers, like other professionals, occasionally have to relocate to a whole new country with a distinct culture due to job opportunities. As a result of this international mobility, English language teachers have to make various adaptations to their new professional environment. One of the changes that may affect the English language teachers is their teachers' identity. Zacharias (2010) argued that "teacher identities can shift when these teachers shuttle between one context and another due to immigration" (p.181). Studies (Wenger, 2010; Pennington \& Richards, 2016; Eslamdoost, King \& Tajeddin, 2019) have shown that teacher identity is fluid and dynamic, as it can alter based on the setting in which one finds themselves. A few earlier research investigated how a shift in the sociocultural context influences teachers' professional identity formation and building (Mora, Trejo \& Roux, 2016; Scotland, 2014; Xu, 2013).

The identities that teachers assign themselves and others are crucial to the subjects they teach and their relationships with students (Pennington \& Richards, 2016). This means that teachers' identities are crucial to their decision-making about their profession and how they approach their teaching methods. Teachers' identities have also been demonstrated to have a substantial impact on their performance and development (Yazan, 2019). Understanding how English language teachers construct identities is important because how they see themselves as professionals influences their pedagogical choices, and classroom practises (Pennington \& Richards, 2016; Eslamdoost, King \& Tajeddin, 2019; Widodo, Fang \& Elyas, 2020).

Although a great deal of research has been conducted on teachers' professional identity around the world, none to our knowledge has examined the ways of EFL teachers' identity formation in an ESL context. In this current study, the teacher's professional identity is related to the way the individual sees themselves as teachers of EFL in the context of the country, in this case, the Saudi School in Kuala Lumpur, Malaysia.

The Kingdom of Saudi Arabia has established schools in various countries around the world. The Saudi Ministry of Education appoints teachers who are posted to those schools across the world. Some of these schools are in countries where English is considered a second language (ESL). Among these countries is Malaysia, which hosts the Saudi School in its capital city, Kuala Lumpur. Before posting them to the Saudi School in Kuala Lumpur, the EFL teachers were formerly teachers in Riyadh, Saudi Arabia.

The Saudi teachers teaching in the Saudi School in Kuala Lumpur is then likely to renegotiate their identity due to their new professional environment and even settling in an entirely different country that has its own social and educational attributes. To better understand how these EFL teachers teach English in different socio-cultural settings, how they see their positions in this English as a second language context, we need to gain insight into how EFL teachers shape their professional identities in relation to their community of practice.

Therefore, this study examines the professional identity formation of the EFL teachers in an ESL setting where language teachers' identities are seen as multiple and dynamic. The main objective of this research is to explore the contextual factors that contribute to the professional 
Arab World English Journal (AWEJ) Volume 12. Number 3. September 2021

Factors Influencing Non-Native EFL Teachers' Identity Construction

Othman\& Aljuhaish

identity formation of three EFL teachers in the Saudi School in Kuala Lumpur. This study addresses the following research question:

1.What sociocultural factors influence the construction of non-native EFL teachers' professional identity in an ESL setting?

\section{Literature Review}

Professional identity is an integral aspect of the teaching profession. The notion of identity offers teachers a structure to form their views on how to behave concerning their practices. Although no clear definition of the term 'professional identity' is available, it has been defined by many researchers as an ongoing process that combines personal and professional notions of being a teacher (Losano, Fiorentini \& Villarreal, 2018; Pennington \& Richards, 2016). Some of the studies suggested that professional identity may be related to the teachers ' selfimages or concepts (Day, 2011; Varghese, Motha, Park, Reeves \& Trent, 2016). It has been argued that such concepts or self-images may have a direct effect on the teachers' way of teaching, growth and attitude towards the changes in the educational system.

Beijaard, Meijer and Verloop (2004) argue that the identity of a teacher continues to evolve and involves two sides that are strongly interwoven: the teacher's ideas accumulated based on their personal experience, and ideas or expectations imposed by the social context. The factors influencing teacher identity formation were associated with the socio-cultural experiences of the teachers. In conjunction with changing contextual elements that include the family, classroom, school, and society, these factors were described as constantly developing.

Many studies investigate the economic and sociopolitical factors that help in the formation of the identities of EFL teachers (Gu \& Benson, 2015; Varghese et al. 2016; Wolf \& De Costa, 2017). Huang and Varghese (2015) stated that the professional identity of the teachers is an important parameter and is based on the sociopolitical and socio-cultural environment of a classroom and their professional development. Teachers also suffer from an identity crisis when they migrate from one environment to another (Sarasa, 2016). The influence of the change of environment on teacher identity is an issue that also has been noted by Wenger (2010), who argued that teacher identity alters depending on the environment one finds himself/herself in. According to Wolf and De Costa (2017), the influence of the change of environment on teacher identity is an under-researched area. Among the three studies that investigated how teachers adapted to new school contexts and negotiated their profession of identities in various educational settings are (Mora, Trejo \& Roux, 2016; Said, 2014; Xu, 2013). Their findings revealed the critical influences of past learning and work experiences of language teachers in shaping their teaching practices.

Scholars assert that few studies have been carried out on the development of language teachers' professional identity from the Saudi Arabia perspective (ur Rahman \& Alhaisoni, 2013; Elyas \& Badawood, 2016; Aljuhaish, Othman \& Senom, 2020). Most of the studies in the Saudi context investigate the impact of language teaching, teaching methodology and learning in general. Thus, it is essential to examine the construction of teachers' identity in Saudi schools in other countries since the findings of this study could fill the gaps in the existing literature. 
Among the few studies carried out on the Saudi Arabia context, is the study of Ahmad, Latada, Shah and Wahab (2017) who investigated the main factors that develop the professional identity of Pakistani EFL teachers in Saudi Arabia. They found several factors such as interaction with other EFL teachers, their professional futures, the impact of their overseas EFL experience, the social influence on their own professional identity, and the decision to become EFL teachers. Furthermore, Elyas (2011) conducted in-depth semi-structured interviews with one male Saudi teacher teaching in a college in the Kingdom of Saudi Arabia to explore how he sees his identity. The study shows that the teacher embraces his role as a Muslim person rather than an English teacher. He believed that his beliefs and values occupy an essential role in his professional identity. He expressed his insecurity about his identity as a teacher due to some values promoted in the English textbook, in which he believed that these values are opposed to Islamic teaching. In a recent study on non-native EFL teachers in a Saudi secondary school, Aljuhaish, Othman and Senom (2020) reported that their educational background, life experiences and teaching community seem to influence their professional identities as English teachers in Saudi Arabia.

Taking EFL teachers' identity into consideration, the literature shows few studies that examine ESL context, and most previous studies focus on EFL teachers' identity in either English as first or foreign language context. Thus, it is important to examine cross-cultural variation regarding identity formation in the ESL setting.

\section{Methods}

As the aim of this study is to explore the factors that have an impact on professional identity formation in the context of EFL teachers, a qualitative case study design was used. The case study offers insight into the phenomenon being studied, teacher learning, as it exposes reallife situations.

\section{Research Context}

The Saudi School in Kuala Lumpur, Malaysia was established in 1991 and were officially recognised by the Malaysian Ministry of Education as official public schools. The Saudi Ministry of Education and the Saudi Ministry of Foreign Affairs provide the schools with the required teachers, curriculum, teaching materials as well as supervise the teaching and learning processes at the schools. They also appoint the principal and the vice-principal. Furthermore, the schools adhere to the Saudi Ministry of Education in all their rules and regulations and implement the Saudi curriculum.

\section{Participants}

Three Saudi EFL secondary teachers from the Saudi School in Kuala Lumpur, Malaysia participated in this study. The participants were previously teachers at the Saudi intermediate levels and have been assigned to teach secondary levels starting from the academic year 20172018. These participants are expected to have a minimum level of English language proficiency, making it an essential component in the teacher's identity construction process. Below, participants' profile is shown in table one. All names of individuals in this study are pseudonyms. 
Arab World English Journal (AWEJ) Volume 12. Number 3. September 2021

Factors Influencing Non-Native EFL Teachers' Identity Construction

Othman\& Aljuhaish

Table 1. Participants' profile

\begin{tabular}{llll}
\hline Name & Gender & Educational background & $\begin{array}{l}\text { Years of working in Saudi schools } \\
\text { in Kuala Lumpur and Riyadh }\end{array}$ \\
\hline Ismail & Male & Bachelor's degree, English Education & $\begin{array}{l}\text { Three years in Saudi School in } \\
\text { Kuala Lumpur }\end{array}$ \\
Najwa & Female & Bachelor's degree, English Literature & $\begin{array}{l}\text { Three years in Saudi School in } \\
\text { Kuala Lumpur }\end{array}$ \\
Majid & Male & $\begin{array}{l}\text { Bachelor's degree, English language, } \\
\text { and Literature }\end{array}$ & $\begin{array}{l}\text { Two years in Saudi School in Kuala } \\
\text { Lumpur }\end{array}$ \\
\hline
\end{tabular}

Ismail is a 31-year-old English teacher at the Saudi School in Kuala Lumpur. English is his foreign language which he has been learning for 20 years in school, university and after graduation. He graduated with a bachelor's degree in English education from King Saud University in Saudi Arabia. He took numerous courses in the English language and attended many workshops on how to teach English as a foreign language. When he moved to Malaysia, he took various courses provided by the Saudi School in Kuala Lumpur, which helped him to develop professionally. He took IELTS twice.

He has been teaching English for five years, three of which were in Riyadh (Saudi Arabia) and two in Kuala Lumpur (Malaysia) He moved to Malaysia two years ago from Saudi Arabia as an appointment from the Ministry of Education to teach English at the Saudi schools in Kuala Lumpur. He is currently pursuing his master's degree at a local public university in Kuala Lumpur.

Najwa is a 38-year-old English teacher at the Saudi schools in Kuala Lumpur. English was her favourite subject in school. Najwa graduated with a bachelor's degree in English literature from King Saud University in Riyadh. She has been teaching English for three years. Najwa moved a year ago to Malaysia from Saudi Arabia as an appointment from the Ministry of Education to teach English at the Saudi schools in Kuala Lumpur.

As she majored in English literature at the university, she had very little pedagogical knowledge about teaching methodologies. For this reason, Najwa had to bridge this gap in her teaching career. She simply read books about teaching methodologies and learned from her colleagues' teaching experiences. She believes that having adequate linguistic knowledge comes first. When she attended the online courses administered by Saudi School in Kuala Lumpur, she learned new teaching methods. The teachers also used to exchange classroom visits, and that gave her the chance to learn new things from her colleagues.

Majid is a 33-year-old English teacher at the Saudi School in Kuala Lumpur. English is his foreign language, yet favourite subject, which he has been learning since fifth grade for almost 15 years in school, university and after graduation. He majored in the English language and graduated from King Saud University in Saudi Arabia. Majid used to watch T.V. 
programmes in the English language, and he also used to read online English newspapers and magazines to develop his abilities in mastering the English language.

Majid has two and a half years of teaching experience at the Saudi School in Kuala Lumpur. He is currently pursuing his doctorate at a local public university in Malaysia. Before he came to Malaysia, Majid took English courses at the British council and several online courses. Majid is actively involved in courses and workshops organised by the Saudi School in Kuala Lumpur as part of his professional development. He believes that online English courses are very helpful to enhance his skills in the English language.

\section{Research Instruments}

In-depth interviews were utilised in this study. The researchers adopted what Kvale (1996) and Cohen, Manion \& Morrison (2007) called 'semi-structured interview'. This type of interview has questions to be posed, and a structure of themes to be conveyed (Kvale, 1996). In a case study, semi-structured interviews are recommended since they help the researchers to build the research interviews in a way that preserves the pre-prepared researcher's questions to contain any emerging ideas and information offered by the subjects which in turn provide detailed information of the subjects' perspectives (Drever, 1995). The participated teachers were asked to evaluate and describe their perspectives on factors that have an impact on professional identity formation. All the interviews were audiotaped and immediately transcribed. Besides, the study utilised classroom observation by observing two classes for each of the three teachers. Classroom observation allows the researchers to describe and write down actions and interactions, following the behaviour of subjects in individual classroom settings (Marshall \& Rossman, 2006). The data collection was completed within 12 weeks and until data saturation as a prolonged engagement to ensure trustworthiness.

This study draws on Wenger's (1998) communities of practice framework to analyse and interpret the data. The communities of practice are "groups of people who share a concern, a set of problems, or a passion about a topic and who deepen their knowledge and expertise in their area by interacting on an ongoing basis" (Wenger, McDermott, \& Snyder, 2002, p. 4). Wenger reports three essential features for COP: (1) mutual engagement: participants' engagement needs to be encouraged by a community of practice. This indicates that participants are encompassed in a community of practice, in an engagement that clarifies belonging; (2) joint enterprise: it is the result of negotiation, and it mirrors the total complexity of mutual engagement as well as establishes relationships among participants.

\section{Data Analysis}

Marshall and Rossman's (2006) seven analytical stages were chosen to guide the data analysis of this study. This involves 1) organising the data; 2) immersing in the data; 3) generating categories and themes; 4) coding the data; 5) offering interpretation; 6) searching alternative understandings, and 7) writing the findings. To synthesise the data, the researchers identified some significant themes that are linked together and collectively described the Saudi EFL teachers' teaching experience. 


\section{Findings}

The study identifies the factors that influence the professional identity formation of the three teachers. The findings of the study are presented and discussed under the following categories:

\section{Positive Teaching Environment}

The school environment provides great opportunities through participation in grouporiented activities, along with shared responsibilities and goals. Teachers who participate as members of a community of practice, work and learn together with their colleagues and acquire skills that affect their professional identities. In this regard, the interviewed teachers were asked about their experience with life in their school environment (where they teach). Teacher Ismail feels that the school is a fantastic environment, and he enjoys teaching as his students consider themselves native English speakers. He discloses:

Ah, teaching... is fantastic because I enjoy teaching students who considered to be native speaker of the English language... I learn a lot of things.

The connection of the teachers in communities of practice develops their professional identities through sharing their experiences, beliefs, and values. Teacher Najwa describes her experience as a lucky being a teacher in her school due to the friendly work atmosphere in the school. She elaborately explains:

I always say that I am lucky enough to be a teacher there. My school has a friendly work atmosphere. My colleagues are amazing in many ways. We always share ideas and experiences... We all believe that our main message is to make our students learn English with fun.

Teacher Majid also shares some of the views made by teacher Najwa. He sees his school environment as "a great experience" different from all his past experiences. He clarifies:

We live in a different society, different country, or foreign country in EFL environments... we are dealing with a different kind of proficiency of English language at the same time in the same class...I have a great experience with other teachers in the school...we share our experiences and ideas regarding teaching methods and students' progress. I can say that I teach in a very friendly environment

His feelings about the environment have to do with the different proficiency levels of the students he teaches because some of the students have relatively high levels of proficiency as a result of their living in Malaysia for some time, though other students have a low level of proficiency.

\section{Supportive Members in the Community of Practice}

Schools are made up of teachers from different backgrounds working together to teach their respective subjects. Even though the teachers mostly teach different subjects, they need each other's support for the maximum outcome. The supportive members in the community of practice promote the formation of their professional identities in terms of increasing their abilities, developing their skills, discovering their potentials and providing courses. Thus, the teachers were asked to assess the role of the school in promoting or hindering their professional development and whether there are opportunities for continual learning and professional 
development. The three teachers acknowledged the support of their colleagues and the administrative staff. Teacher Najwa, for example, acknowledged that the school gives her opportunities to discover her potential. She reveals:

One of the best advantages of our school is that we are given chances to discover our potentials. The school does not impose on us what strategies to teach with. Every semester, the school organizes the exchange of classroom visits. During the visit, teachers fill in evaluation forms. Then the teacher gets feedback regarding the positive and the areas that need support.

Teacher Majid was more specific in his response. He acknowledged that the school gives him opportunities for online courses. He discloses:

Well, in our school we have to attend online courses provided by Saudi schools in Kuala Lumpur as free courses... and some courses of training and following up with the teachers and everything we do. So, it is a great opportunity to develop ourselves and when your personal or professional, when you like professional what they want, so they make it very professional for us at Saudi school in KUALA LUMPUR.

\section{A Good Relationship with Students and their Parents}

The teachers were asked about their relationship with the students and their parents. Teacher Ismail responded by claiming that he is friendly with both of them. He said:

I can say my relationship with my students is so friendly, and also so friendly with the parents.

The same response was also given by teacher Najwa adding that:

I have very good relations with both of them. They both understand that my comments are for the advantage of the student. Even though I am known to be strict, I always find support from parents to be stricter with their children! I always receive respect and appreciation from my parents.

Teacher Majid stated that he is in touch with the parents. He claims:

I in touch with the parents, because usually, I ask about the kids' performance and their level in English... which is important to make them updated with the hmmm, kids' situations inside and outside the class.

All three teachers claimed to have a great relationship with both the students and their parents. This can relate to the reason why the teachers are happy in the community of practice given the fact that a teacher is unlikely to be happy if there is a conflict of interest between themselves and their students or their parents. It could also be related to the fact that the parents' value what the teachers do. The teachers were asked whether the parents value English language education and whether they have had experiences with parents that affected their teaching or made them aware of their attitudes towards language instruction for their children. The three teachers acknowledged that the parents considerably value English language education. Teacher Najwa, for example, elaborately elucidates:

Parents considerably value the importance of learning English...most of our students' parents are students in universities and study in English. Based on their passive learning experiences..., they ask me to communicate with them to ensure that their children take 
English classes seriously. When I meet parents, I listen carefully to their feedback.... At this point, I correct any misconceptions and benefit from criticism to improve my teaching. I always encourage parents to have more parental influence on their children...teacher-parent connections are very important. I have successfully created effective communication with them. In many cases, I noticed that a student's attitude towards learning English positively changed after I talked to the mothe

Furthermore, teacher Majid thinks that parents care more about English language learning in Malaysia than in Saudi Arabia. He elaborates:

I think they care more than in Saudi Arabia...because they realize when they come here, this is an English language speaking country.... they want the kids to speak this language to communicate. Sometimes the parents cannot speak; they just put the kids and let them speak on their behalf.

\section{Saudi EFL Teachers' Professional Development in Malaysia}

With regards to professional development opportunities in Malaysia, teacher Ismail stated that the professional development of Saudi EFL teachers in Malaysia looks good, whereas in Saudi Arabia teachers are restricted by the environment. He points out:

In Malaysia, I think the future is good because of the source of learning the English language and because the English language in Malaysia is the second language.... But in Saudi Arabia, teachers are restricted with the environment, and they have problems with the learning situation there because they have limited time to teach English.

Teacher Najwa also opined that teaching in Malaysia is "an exciting experience" because "the school is well-resourced".

With regards to how being a member of the community of practice in Saudi School in Kuala Lumpur, Malaysia is different from being a member of a community of practice in Riyadh, Saudi Arabia. The three teachers confirmed that a teacher has a better chance of improving their teaching style and developing their abilities and skills by being a member of a community of practice in the Saudi School in Kuala Lumpur. Teacher Najwa, for example, argued that in the community of practice in Saudi School in Kuala Lumpur, teachers are from different countries and different educational levels, and there is a high sense of cooperation among teachers. She adds:

The interactions between teachers are effective. There is a high sense of cooperation. In other words, the staff in our school is professional. The school admin always seeks to find down-to-earth solutions to any problem...one meeting with the school admin is equal to an intensive training course. I see that I learn significant tips on how to deal with various problems in school.

Teacher Majid also claimed that in Riyadh, there is poor communication between teachers, whereas, in Kuala Lumpur, teachers sit with each other sharing their experiences concerning new teaching methods or other matters of their concern. He elucidated further:

...in Riyadh, there is poor communication between the teachers unlike the situation in

KUALA LUMPUR where teachers sit with each other sharing their own experiences 
regarding the new teaching methods and discussing among each other about the students' progress. The medium language of communication in KUALA LUMPUR is in the English language unlike the teachers in Saudi Arabia where teachers discuss unrelated and random topics in the Arabic language.

In terms of understanding the professional relationships, the teachers were asked to describe their professional relationship with their peers, professional organizations, and the wider professional community. Teacher Ismail began by claiming that there are more chances to engage with different organisations and communities in Malaysia. He explains:

In Malaysia, I have a lot of chances to interact with my peers and professional organisation like American organisations, and also, I can contact a wide professional community and get benefits from them and get benefits what new method is. But in Saudi Arabia the situation is different, the chances are not too much to engage with these people.

Teacher Najwa also claimed that she has quite a professional relationship and there is respect among them. She claims:

It is quite professional in the sense that I do have effective communication with everyone I come into contact with. There is remarkably mutual respect. And this is the main reason how the job gets done at the right time and in an effective way... When the school admin appoints a new task for me, I just appreciate it as a kind of trust. The nice thing about our school is that we are open to exchange experiences. We listen to each other.

As for teacher Majid, he claimed to have also been in touch with language institutions that are based in Malaysia. He made his point clear in the following words:

We are in touch. Like we are in touch with the local level, like with the social work and other language centres...because sometimes we develop some courses for the kids and we take some case studies, you know, and other schools, like Malaysian school, international school. We do some programmes and support each other, and we have some visits just to develop to see how we can reach the international level like them.

The teachers were then asked to describe their professional careers at this point. Teacher Ismail claimed to be satisfied with his knowledge and his methods of teaching the English language as a foreign language. He clarifies:

I get a lot of information, especially after moving from Saudi Arabia...I feel more confident, and I feel I am more satisfied with my knowledge and my new methods of teaching the English language a foreign language...

Teacher Najwa sees herself as professional and responsible. She said, "I can say that I am committed and responsible. However, there is a lot to learn". A similar response was also given by teacher Majid who feels that he is "doing good so far" and that "he is responsible and committed" to his career.

\section{The Teachers' Notion of being a Teacher}

The teachers were asked about how they feel about being teachers, how they understand teaching in their lives and what it means to them. Teacher Ismail stated that what teaching means 
to him is like being "a father of more than 600 students" and that whose minds "you are creating and shaping", which gives him much responsibility.

Teacher Najwa argued that she likes teaching, though she felt that it is a demanding job. She elaborates:

It is a demanding job. However, I like it, especially when I see the impact of my hard work reflected on students' learning outcomes. I like to share knowledge and experiences, whether with students or colleagues. I view teaching as a job mainly concerned with information transmission and character transformation. Being a teacher means a lot to me. It is part of me now. When I meet a person for the first time, he/she immediately labels...

Teacher Najwa claimed she likes teaching because of the impact she makes on her students which is what she felt about some of her remarkable English teachers in her school and university days. This view is similar to that of teacher Majid, who perceives teaching as a wonderful career that delivers knowledge and education to people. He says:

I think teaching is a wonderful thing that you can deliver knowledge and education to people...you already happy when you see the results...you feel very proud. Teaching means a lot to me. I share knowledge not only with students but also with my peers and colleagues.

The views of the three teachers show that each one of them has a positive but unique view about teaching and the role it plays in their lives.

\section{Discussion}

This study aims to find out what factors influence the construction of the non-native EFL teachers' professional identity in an ESL environment. It reported several major findings.

First, a positive teaching environment plays an important role in motivating the EFL teachers to participate in their community of practice and share responsibilities and goals with their peers. As Pennington and Richards (2016: p.15) points out when "favouring conditions prevail, it is more likely for teachers to achieve a good match between their teaching ideals and their classroom identity and so easier for them to maintain high motivation in their work".

Second, the findings of this study showed that the supportive members of the community of practice seem to promote their professional identities formation in terms of their pedagogical skills and linguistic competencies. The English-speaking environment in Kuala Lumpur enables them to practice their English language widely. It is worth noting that the study's setting is a capital city of Malaysia that offers greater exposure to linguistic and cultural diversities inherent in a cosmopolitan setting. The teachers may develop a more open attitude toward English language use and imagine a legitimate identity as non-native English teachers in the global context. This result also concurs with Zacharias (2010) and Wenger's (2010) finding that a teacher's professional identity can change when they move from one environment to another.

Social and affective factors like teacher-pupils and teacher-parents good rapport also played an important role in the formation of the EFL teachers' positive teacher identity. Teachers and pupils are collaborators in the school context. To foster a conducive environment, students 
and teachers must maintain a positive and healthy interaction. The Saudi English language teachers in Kuala Lumpur also claims that they have the flexibility in terms of their pedagogical choices as their students in Kuala Lumpur are more motivated to acquire the English language. This allows the teachers to be more creative in their classroom practices.

Finally, in terms of professional development opportunities in Malaysia, the Saudi EFL teachers said that they benefited from having access to various teacher training courses available in Malaysia. This result suggests that shifting professional settings facilitates teachers' professional identity development. These findings are in line with those of Scotland (2014), Gu and Benson (2015) and Yang and Jang (2020) studies. Focusing on the English language teachers' professional identity construction, this study reflects Pennington and Richards (2016) observation that:

One's identity as a teacher is relative to a particular national or regional and school culture, reflecting the nature of the students, other teachers, and school leadership and administration. A teacher's classroom and professional identity development within these cultural frames or cultures of learning, which are interactive with the teacher's background characteristics and experience, including educational experience within similar or different cultures. (p. 15).

\section{Conclusion}

This study has enhanced our understanding of non-native EFL teachers' identity construction in an ESL setting. It adds to our knowledge of how sociocultural factors have an impact on EFL teachers' professional identities. More studies of teacher identity formation could be conducted in other Saudi schools in ESL settings around the world, to see how teachers, as reflective agents, construct their identities. In an era of globalisation, such a cross-cultural comparison study would provide vital information to teacher educators, institutional administrators, and policymakers, allowing them to improve education quality and stay current with international development. A global support network for English language teachers to share experiences, ideas, advice, and information would be beneficial. Future studies should explore other contexts such as the perceptions of a larger number of EFL teachers employed in other ESL context would provide further valuable insights into the identity constructions of English language teachers.
About the Author:
Dr. Juliana Othman is an Associate Professor at the Faculty of Education, University of Malaya. Dr Juliana has authored and co-authored several books, chapters and articles on issues in ESL teacher professional development, preservice teacher education, second language pedagogy and content-based instruction. https://orcid.org/0000-0001-5151-099X

Dr. Sultan Fahd Aljuhaish is working as education supervisor at Ministry of Education in Saudi Arabia. Sultan has authored and co-authored several articles on ESL/EFL teacher professional development. https://orcid.org/0000-0001-5038-8080

\section{References}

Ahmad, H., Latada, F., Shah, S. R. \& Wahab, M.N. (2017). Exploring the Construction of Professional Selves of Non-native EFL Teachers at a Saudi Arabian University. Arab 
World English Journal, 8 (4), 229-239. DOI:

https://dx.doi.org/10.24093/awej/vol8no4.10.

Aljuhaish, S.F., Othman, J., Senom, F. (2020). Saudi EFL Teachers' Identity Formation in

Saudi Schools: A Case Study. Arab World English Journal, 11 (3) 431- 445.

DOI: https://dx.doi.org/10.24093/awej/vol11no3.27

Beijaard, D., Meijer, P. C., \& Verloop, N. (2004). Reconsidering research on teachers' professional identity. Teaching and Teacher Education, 20(2), 107-128. http://dx.doi.org/10.1016/j.tate.2003.07.001

Cohen, L., Manion, L., \& Morrison, K. (2007). Research methods in education (6 $6^{\text {th }}$ ed.). USA and Canada, Routledge.

Day, C. (2011). Uncertain Professional Identities: Managing the Emotional Contexts of Teaching. In C. Day, \& J. C. K. Lee, (eds.), New Understandings of Teacher's Work: Emotions and Educational Change (pp. 45-64).- New York: Springer.

Drever, E. (1995). Using Semi-Structured Interviews in Small-Scale Research: A Teacher's Guide. Edinburgh: Scottish Council for Research in Education.

Elyas, T (2011). Teacher Education and Identity in Saudi Arabia and Real-life Conflicts: A Case Study. In C. Coombe, L. Stephenson, \& S. Abu Rmaileh, (eds.), Leadership and Management in English Language Teaching (pp. 137-146 ). Dubai: TESOL Arabia Publications

Elyas, T., \& Badawood, O. (2016). English Language Educational Policy in Saudi Arabia Post 21st Century: Enacted Curriculum, Identity, and Modernisation: A Critical Discourse Analysis Approach. FIRE: Forum for International Research in Education, 3(3), 70-81. DOI:10.18275/fire201603031093

Eslamdoost,S., King, A.K., \& Tajeddin, Z. (2019). Professional Identity Conflict and $(\mathrm{Re})$ Construction among English Teachers in Iran. Journal of Language, Identity \& Education, 19(5), 327-341. DOI: 10.1080/15348458.2019.1676157

Gu, M., \& Benson, P. (2015). The formation of English teacher identities: A cross-cultural investigation. Language Teaching Research, 19(2), 187-206. DOI: $10.1177 / 1362168814541725$

Huang, I., \& Varghese, M. (2015). Toward a Composite, Personalized, and Institutionalised Teacher Identity for Non-Native English Speakers in U.S. Secondary ESL Programs, Critical Inquiry in Language Studies, 12 (1) 51-76. DOI: 10.1080/15427587.2015.997651.

Kvale, S. (1996). Interview Views: An Introduction to Qualitative Research Interviewing. Thousand Oaks, CA: Sage Publications.

Losano, L., Fiorentini, D., \& Villarreal, M. (2018). The development of a mathematics teacher's professional identity during her first year of teaching. Journal of Mathematics Teacher Education, 21, 87-315. DOI:10.1007/s10857-017-9364-4.

Marshall, C., \& Rossman, G. B. (2006). Designing qualitative research (4th ed.). London: Sage Publications.

Mora, A., P. Trejo, Roux, R. .(2016)The Complexities of Being and Becoming Language Teachers: Issues of Identity and Investment. Language and Intercultural Communication, 16 (2), 182-198. https://doi.org/10.1080/14708477.2015.1136318

Pennington, M. C., \& Richards, J. C. (2016). Teacher identity in language teaching: Integrating personal, contextual, and professional factors. RELC Journal, 47(1), 5-23. DOI: $10.1177 / 0033688216631219$ 
Said, S. B. (2014). Teacher Identity Development in the Midst of Conflicting Ideologies. In Y. L. Cheung, S. B. Said, \& K. Park, (eds.), Advances and Current Trends in Language Teacher Identity Research (pp. 148-160). London, England: Routledge.

Sarasa, M. C. (2016). A Narrative Inquiry into Preservice English Teachers' Imagined Identities. Education and Learning Research Journal, (12), 96-114.

Scotland, J. (2014). Operating in global contact zones: How pedagogical adaptation to local contexts may result in the renegotiation of the professional identities of English language teachers Teaching and Teacher Education 37, 33-43, DOI: 10.1016/j.tate.2013.09.002

Ur Rahman, M. M., \& Alhaisoni, E. (2013). Teaching English in Saudi Arabia: prospects and challenges. Academic Research International, 4(1), 112-118.

Varghese, M., Motha, S., Park, G., Reeves, J., \& Trent, J. (2016). In this Issue. TESOL Quarterly, 50(3), 545-571. https://doi.org/10.1002/tesq.333

Wenger, E. (1998). Communities of practice: Learning, meaning, and identity. Cambridge: Cambridge University Press. https://doi.org/10.1017/CBO9780511803932

Wenger, E. (2010). Communities of practice and social learning systems: the career of a concept Social learning systems and communities of practice. In C. Blackmore, (ed.), Social Learning Systems and Communities of Practice (pp. 0179-198). London: Springer. https://doi.org/10.1007/978-1-84996-133-2_11

Wenger, E., McDermott, R., \& Snyder, W. (2002). Cultivating communities of practice: a guide to managing knowledge. Boston, Mass: Harvard Business School Press.

Widodo,H.P., Fang, F. \& Elyas,T., (2020). The construction of language teacher professional identity in the Global Englishes territory: 'we are legitimate language teachers', Asian Englishes, 22(3), 309-316, DOI: 10.1080/13488678.2020.1732683

Wolf, D., \& De Costa, P. I. ( 2017). Expanding the Language Teacher Identity Landscape: An Investigation of the Emotions and Strategies of an NNEST. The Modern Language Journal, 101(S1), 76-90. https://doi.org/10.1111/modl.12370

$\mathrm{Xu}, \mathrm{H}$. (2013). From the Imagined to the Practiced: A Case Study on Novice EFL Teachers' Professional Identity Change in China. Teaching and Teacher Education 31, 79-86. DOI: 10.1016/j.tate.2013.01.006

Yang, J., \& Jang, I.C. (2020) The everyday politics of English-only policy in an EFL language school: practices, ideologies, and identities of Korean bilingual teachers, International Journal of Bilingual Education and Bilingualism, 1-13 DOI: 10.1080/13670050.2020.1740165

Yazan, B. (2019). Identities and ideologies in a language teacher candidate's autoethnography: Making meaning of storied experience. TESOL J. 2019; Vol. (10).1-15.

Zacharias, N. T. (2010). The evolving teacher identities of 12 South/East Asian teachers in U.S. graduate programs, (Unpublished Doctoral Dissertation). Indiana University of Pennsylvania. 